\title{
Moje wspomnienia z pracy we wrocławskiej Klinice Dermatologicznej
}

\author{
Barbara Gąsior-Chrzan \\ Department of Dermatology, Institute of Clinical Medicine, University of Tromsoe, Norwegia
}

Dermatol Rev/Przegl Dermatol 2020, 107, 195-197

DOI: https://doi.org// 0.5। |4/dr.2019.85582

Ponad 50 lat temu (w 1967 r.), będąc studentką piątego roku medycyny, marzyłam o specjalizowaniu się w dermatologii i jako wolontariuszka przychodziłam do Kliniki Dermatologicznej we Wrocławiu dwa razy w tygodniu na kilka godzin.

Po zakończeniu II wojny światowej w wyniku zmiany granic przesiedlono tutaj ludzi ze wschodnich terenów Polski. Kadra uniwersytecka pochodziła głównie ze Lwowa.

W latach 60. XX wieku większość gruzów w centrum miasta była już usunięta, ale wciąż jeszcze widoczne były zniszczenia.

W czasie walk o miasto budynek kliniki dermatologicznej uniknął zniszczeń. Solidne mury wykonane z licowanej cegły z ciemnozielonymi ceramicznymi ozdobnymi elementami podkreślają jego neogotycką urodę. W zwieńczeniach ściany frontowej dobrze widoczne gwiazdy Dawida przypominają o fundatorze kliniki Kaufmanie, właścicielu fabryk bławatnych w Bielawie i teściu sławnego Alberta Neissera, kierownika kliniki w latach 1882-1916. Po obu stronach głównego wejścia umieszczono elektryczne lampy wykonane w czarnej metaloplastyce.

Budynek ma cztery poziomy. Przyziemie - suterena, której okna chronią dyskretnej urody kraty. Wysoki parter, na który wchodzi się po granitowych schodach, mijając stylowe, solidne, dwuskrzydłowe, drewniane, częściowo przeszklone drzwi wejściowe prowadzące do westybulu w stylu neogotyckim, który nawet dzisiaj robi duże wrażenie na wchodzących. Idąc dalej, napotykamy następne, przeszklone drzwi o lekkiej konstrukcji, przy których siedziała portierka w białym fartuchu. To jej należało zameldować cel wizyty w klinice. Portierka miała pełną kontrolę nad ruchem osób w klinice z wyjątkiem godzin, w których pojawiali się tu w dużej liczbie studenci medycyny.

Wzdłuż głównej osi budynku biegnie przestronny korytarz, z którego na prawo są wejścia do sekretariatu kliniki i gabinetu kierownika - z podwójnymi drzwiami. Tutaj ścianę zdobiły zdjęcia portretowe prof. Jadassohna, Dariera, Jana Lenartowicza (pierwszego powojennego kierownika kliniki w latach 1946-1948). Po przeciwnej stronie gabinetu szefa jest biblioteka $z$ bardzo bogatym zbiorem literatury dermato-wenerologicznej z czasów przedwojennych, głównie w języku niemieckim. Wszystkie tomy są jednolicie oprawione w kolorze ochry. Biblioteka była miejscem pracy Zdzisławy Mamockiej - poliglotki pomagającej pracownikom kliniki w tłumaczeniu tekstów i uczącej niektóre nasze dzieci (m.in. obecnego kierownika kliniki) języka angielskiego. Idąc dalej - po prawej stronie był pokój lekarza dyżurnego, laboratorium, pracownia histopatologiczna skóry, poczekalnie dla pacjentów i gabinety lekarskie. Po lewej stronie znajduje się wejście do dawnej sali wykładowej, obecnie muzeum, wypełnionej przeszklonymi szafami z dobrze zachowanymi mularzami. Na ścianach wiszą obecnie fotografie przedstawiające byłych pracowników kliniki, z czasów przed- i powojennych.

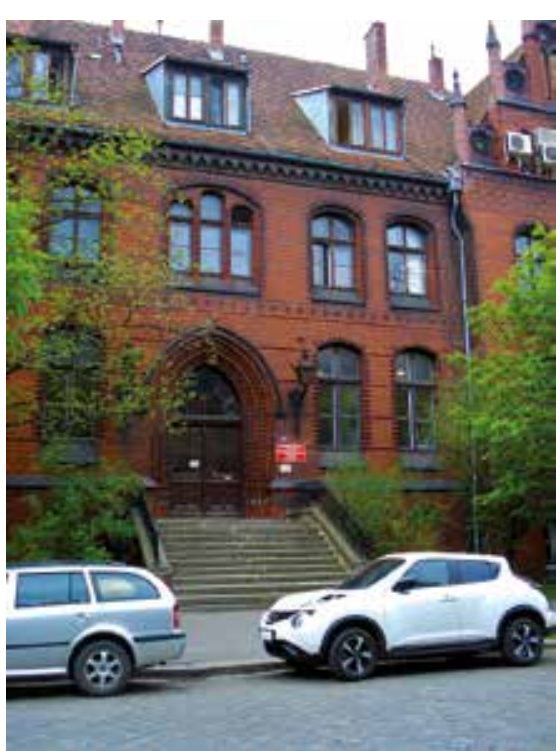

Rycina I. Wejście do Kliniki Dermatologicznej we Wrocławiu (zdjęcie autorki) 


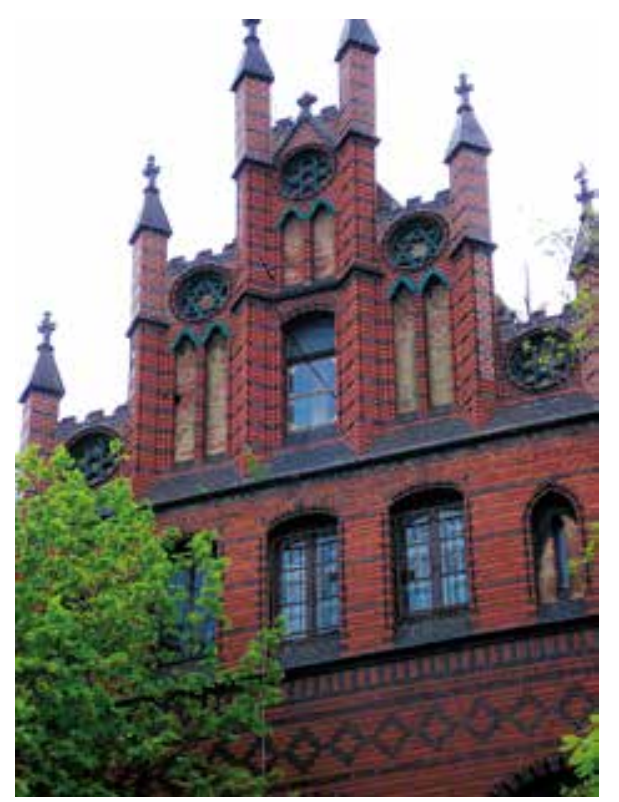

Rycina 2. Gwiazdy Dawida na frontonie budynku Kliniki Dermatologicznej we Wrocławiu (zdjęcie autorki)

W tej sali wykłady prowadził Albert Neisser. Tutaj odbywały się prezentacje trudnych diagnostycznie przypadków. Przed wejściem, trochę z boku po prawej stronie, stała duża, drewniana, biała szafa, a w niej starannie posegregowane czarno-białe fotografie opisane w języku niemieckim dokumentujące choroby skóry pacjentów sprzed wojny. Te dokumenty fotograficzne nie wzbudzały niczyjego zainteresowania.

W sąsiedztwie są dwa pokoje, z których jeden służył pracowni mykologicznej, wówczas jeszcze skromnej. To tutaj pierwsze mykologiczne kroki stawiał późniejszy kierownik kliniki w latach 2001-2012 dr Eugeniusz Baran.

Drugi pokój był pełen szklanych flaszeczek i słoiczków. To była pracownia chorób zawodowych skóry. Tą dziedziną dermatologii zajmował się, wówczas już emerytowany, były kierownik kliniki w latach 1948-1961 prof. Henryk Mierzecki, który przeżył wojnę, pracując w fabryce kosmetyków "Kamea” w Milanówku koło Warszawy. Jego żona Janina była utalentowaną fotografką. Jej prace możemy oglądać w monografii Henryka Mierzeckiego „Ręka pracująca” i „Kosmetyka lekarska”.

Idąc w lewo głównym korytarzem, naprzeciwko głównego wejścia do kliniki zauważymy mały korytarz prowadzący w owym czasie do gabinetów radioterapii skóry, światłolecznictwa i gabinetu kosmetycznego. W tej części kliniki dwaj ważni adiunkci, F. Wąsik i T. Litwiński, mieli wspólny gabinet.

Kierując się korytarzem na północ, mijamy laboratoria i pokoje lekarskie. W końcu lat 70. powstał tam oddział chirurgii plastycznej.
Na pierwszym piętrze były wielkie sale dla hospitalizowanych pacjentów. Największa z nich mieściła dwadzieścia kilka łóżek, ustawionych w czterech rzędach. Łukowate sklepienie sal podpierały cztery okrągłe kolumny. Później sale te przebudowano, podnosząc komfort pacjentów.

Na poddaszu mieściła się szkoła podstawowa dla hospitalizowanych dzieci składająca się z jednej sali lekcyjnej i pokoju nauczycielskiego. Była tam także kilkuosobowa sala dla hospitalizowanych chorych wenerycznie mężczyzn.

W przyziemiu znajdowała się szwalnia, pralnia, prasowalnia, pracownia fotograficzna z ciemnią i składy rozmaitych przedmiotów z czasów wojny: wysmukłych pojemników z żółtą maścią, którą leczono odmrożenia kończyn i twarzy żołnierzy Wehrmachtu mających szczęście powrócić spod Stalingradu, papierów większego lub mniejszego formatu, np. blankietów recept lekarskich $\mathrm{z}$ nadrukowanym nazwiskiem prof. Heinricha Gottrona, kierownika kliniki w czasach nazizmu (1935-1945). W jednym z bocznych pomieszczeń przyziemia znajdowały się pozostałości po dawnym zwierzyńcu. Stały tam wysokie klatki wykonane z solidnych żelaznych prętów, które w swoim czasie zamieszkiwały małpy przywiezione przez Alberta Neissera z wyprawy na Borneo. To na nich prowadzono badania serologiczne i farmakologiczne kiły.

W suterenie mieszkał Andrzej (Jędruś) Limanowski, laborant złota rączka, z doskonale gotującą żoną i dorosłym synem. Pan Limanowski przybył do Wrocławia wraz z innymi lwowiakami i był zawsze dostępny oraz pomocny $\mathrm{w}$ rozwiązywaniu rozmaitych problemów, nie tylko technicznych. Wiele lat później został śmiertelnie potrącony na przejściu dla pieszych tuż przy klinice.

W końcu lat 60. ubiegłego wieku nadal przy przyciemnionym świetle w korytarzu wysokiego parteru czuło się atmosferę wspaniałej przeszłości kliniki, w tym Maxa Jessnera, Hansa Bibersteina, Wilhelma Freia, P.S. Mayera i innych luminarzy międzywojennej niemieckiej dermatologii, a także palącego fajkę prof. Jadassohna.

W okresie powojennym w klinice dermatologicznej we Wrocławiu nie było tradycji wolontariatów studenckich. Profesor Józef Kubicz, kierownik kliniki w latach 1961-1977, po długim patrzeniu na mnie w milczeniu wyraził zgodę, bym przychodziła dwa razy w tygodniu przyglądać się pracy lekarzy. Doktor Tadeusz Litwiński, przyjaciel profesora jeszcze z czasów lwowskich, adiunkt kliniki, został wyznaczony na mojego opiekuna.

Profesor Józef Kubicz w czasie wojny pracował w Instytucie Weigla we Lwowie przy produkcji szczepionki przeciw tyfusowi. Znał technikę hodowli zarazków na jelicie wszy. Uważał, że większość chorób 
skóry jest spowodowana specyficzną „noksą”. Gdy nie udała się identyfikacja tej „noksy”, jego zainteresowania skupiły się na diagnostyce chorób skóry. Opisał kilka zespołów skórnych. Wspólnie z dr. Masiakiem opracował i opatentował Linomag na długo przed tym, zanim zaczęto lansować kwasy omega-3. Interesowały go także podstawowe problemy fizyki i problemy społeczne. Kolekcjonował przedmioty sztuki. Mówił cicho i niewyraźnie, sprawiając wrażenie człowieka nieprzystępnego. W budynku kliniki przebywał codziennie do późnych godzin wieczornych.

Doktor Litwiński był bez wątpienia najlepszym diagnostą chorób skóry. Znał biegle język niemiecki i w tamtych trudnych także dla nauki czasach czytał „Der Hautarzt". Wtedy diagnozę pisało się po łacinie i nierzadko pojawiały się niepewności dotyczące deklinacji. Znając łacinę, rozstrzygał ten problem. Miałam to szczęście, że był moim osobistym nauczycielem dermatologii.

Klinika nie miała wówczas zdefiniowanego profilu badań naukowych. Pracownicy starali się sami znaleźć dla siebie jakąś niszę, a prof. Kubicz w to nie ingerował.

Doktor Adam Nowak, adiunkt, odpowiadał za współpracę z przemysłem farmakologicznym. W klinice testowano preparaty dermatologiczne przed wprowadzeniem ich do powszechnego leczenia. Później objął kierownictwo kliniki dermatologicznej w Szczecinie. Doktor Feliks Wąsik, adiunkt i późniejszy kierownik kliniki (1977-2001), znakomity diagnosta, zajmował się także radioterapią skóry. Jego wysoka pozycja w kraju była bardzo przydatna dla kliniki i pozwalała np. na wymianę zużytego sprzętu bądź okresowe remonty budynku. W tamtym czasie nie było to tak oczywiste. Wiele lat później dzięki jego inicjatywie i zaangażowaniu powstał pierwszy w Polsce oddział chirugii plastycznej połączony z kliniką dermatologiczną. Doktor Witold K. Jacyk, który doktoryzował się w klinice, wyjechał do pracy w Afryce. Pierwszym etapem jego pobytu była Nigeria, następnie przeniósł się do Pretorii w Afryce Południowej, gdzie jako profesor był długoletnim kierownikiem uniwersyteckiej kliniki dermatologicznej. Doskonały diagnosta, uważany był powszechnie za największego dżentelmena wśród dermatologów w Afryce.
W klinice pracowały także kobiety lekarki, bardzo inteligentne.

W latach 60. wciąż jeszcze, chociaż rzadko, można było zobaczyć pacjentów w różnych stadiach kiły, jak również różne formy gruźlicy skóry. Duża liczba łóżek pozwalała na hospitalizację 120 chorych na oddziałach żeńskim, męskim i dziecięcym, a później także plastycznym. Dawało to unikalne możliwości edukacyjne młodym adeptom dermatologii i wenerologii. Leczenie prowadzono wówczas z użyciem okładów, przymoczek, maści dziegciowych i antybiotyków. Retinoidy, immunomodulatory, cytostatyki, leki biologiczne oraz lasery weszły do dermatologii znacznie później i zmieniły radykalnie terapię chorób skóry. Zredukowano liczbę łóżek szpitalnych. Przyszli nowi ludzie, entuzjaści dermatologii. Zmienił się profil chorób skóry. Obecny kierownik kliniki (od 2012 r.) prof. Jacek Szepietowski, realizując wciąż nowe projekty badawcze, wprowadził wrocławską klinikę dermatologiczną na salony światowej dermatologii (ustna wypowiedź prof. G. Plewiga).

How to cite this article

Gąsior-Chrzan B.: Moje wspomnienia z pracy we wrocławskiej Klinice Dermatologicznej. Dermatol Rev/Przegl Dermatol 2020, 107, 195-197. DOI: https://doi.org/10.5114/dr.2019.85582. 